\title{
Ellipsis
}

2015

\section{What Home Was}

Jen Hanks

University of New Orleans

Follow this and additional works at: https://scholarworks.uno.edu/ellipsis

\section{Recommended Citation}

Hanks, Jen (2015) "What Home Was," Ellipsis: Vol. 42 , Article 12.

DOI: https://doi.org/10.46428/ejail.42.12.0

Available at: https://scholarworks.uno.edu/ellipsis/vol42/iss1/12

This Poetry is brought to you for free and open access by the Department of English and Foreign Languages at ScholarWorks@UNO. It has been accepted for inclusion in Ellipsis by an authorized editor of ScholarWorks@UNO. For more information, please contact scholarworks@uno.edu. 


\title{
What Home Was
}

\author{
Jennifer Hanks
}

Andrea Saunders Gereighty / Academy of American Poets Award Runner Up

Let's say my mom went out to buy milk one night in a slime-colored raincoat at eleven p.m.

Let's say I heard her leave over the video game where I'm 007, rapid firing at a dirty TV screen.

Let's say the store lights called to her the beasts in the meat packages like new children.

Let's say she thought she could start over

a nursery cows growing back their limbs.

Hide it she thought Under your rain slicker

Let's say she didn't come home for three days and it was nice.

Dry cereal and weed for breakfast, my dogs snacking on sugary crumbs.

I'd walk to the beach and sink into the dirty sand.

The waves would kick up fish The waves would kick up fish

I'd find them still breathing half-dried their gills red as grapefruit

Cut in half so you could pour sugar on top. 
Where were you? I ask her.

She hands me an empty milk carton smells like meat spoiling, like her clothes have absorbed worms of ground beef.

Look she says unzipping the rain slicker What our home can be 